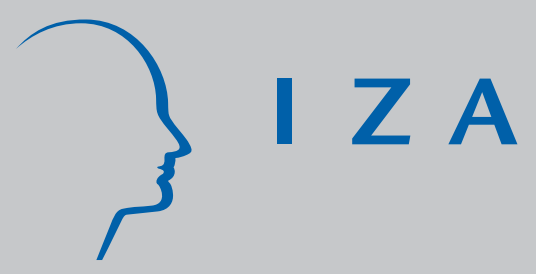

IZA DP No. 1762

The Choice of the Agenda in Labor Negotiations: Efficiency and Behavioral Considerations

Manfred Königstein

Marie-Claire Villeval

September 2005 


\title{
The Choice of the Agenda in Labor Negotiations: Efficiency and Behavioral Considerations
}

\author{
Manfred Königstein \\ University of Erfurt \\ and IZA Bonn
}

\section{Marie-Claire Villeval}

GATE (CNRS, University Lumière Lyon 2, Ecole Normale Supérieure LSH)

and IZA Bonn

\section{Discussion Paper No. 1762 \\ September 2005}

\author{
IZA \\ P.O. Box 7240 \\ 53072 Bonn \\ Germany \\ Phone: +49-228-3894-0 \\ Fax: +49-228-3894-180 \\ Email: iza@iza.org
}

Any opinions expressed here are those of the author(s) and not those of the institute. Research disseminated by IZA may include views on policy, but the institute itself takes no institutional policy positions.

The Institute for the Study of Labor (IZA) in Bonn is a local and virtual international research center and a place of communication between science, politics and business. IZA is an independent nonprofit company supported by Deutsche Post World Net. The center is associated with the University of Bonn and offers a stimulating research environment through its research networks, research support, and visitors and doctoral programs. IZA engages in (i) original and internationally competitive research in all fields of labor economics, (ii) development of policy concepts, and (iii) dissemination of research results and concepts to the interested public.

IZA Discussion Papers often represent preliminary work and are circulated to encourage discussion. Citation of such a paper should account for its provisional character. A revised version may be available directly from the author. 
IZA Discussion Paper No. 1762

September 2005

\section{ABSTRACT}

\section{The Choice of the Agenda in Labor Negotiations: Efficiency and Behavioral Considerations}

The labor economics literature has shown that the "efficient bargaining" model, in which wage and employment are negotiated simultaneously, is less frequently used on unionized markets than the less efficient "right-to-manage" model, in which wage is determined via bargaining and employment determined subsequently and unilaterally by the firm. This paper reports an experiment in which the choice of the bargaining agenda is endogenous within a noncooperative game. We find that participants show a preference for decision authority and choose single-issue bargaining in most cases even though efficiency is lower than in multiissue bargaining. Furthermore, multi-issue bargaining induces unions to offer smaller payoff shares and leads to a higher conflict rate than in a single-issue bargaining.

JEL Classification: $\quad$ C72, C78, C91, J51, J53

Keywords: bargaining agenda, efficient contracts, right-to-manage, decision authority, experiments

Corresponding author:

Marie-Claire Villeval

GATE

93, Chemin des Mouilles,

69130 Ecully

France

Email: villeval@gate.cnrs.fr 


\section{Introduction}

Bargaining between employers and unions usually concerns wages but not the level of employment. The latter is left to the choice of employers. In economic theory this way of determining wage and employment is classically called the "right-to-manage" (RTM) model since employers retain the right to determine employment (Nickell and Andrews, 1983). From a theoretical viewpoint this process of wage and employment determination is inferior to the so-called "efficient bargaining" (EB) model, which assumes that both, wage and employment, are determined simultaneously via bargaining between the two parties (McDonald and Solow, 1981). Under general conditions the latter model yields higher employment (higher efficiency) and lower wage than the RTM-model. Empirically, however, employers and unions seem to follow the single-issue bargaining rule in most cases. The predominance of this restricted agenda is puzzling and its rationale remains still largely undetermined. Behavioral economics can provide some insight and help in understanding this predominance. The aim of this paper is to investigate some of the reasons explaining the preference for a restricted bargaining agenda by means of a controlled laboratory experiment. We can think of the five following reasons.

First, employers may have a preference for a larger degree of decision authority even if this is costly in terms of forgone profit. A single-issue bargaining agenda offers them full discretion over the management of the employment level. Second, unions may feel stronger when they bargain about both, wage and employment, and may therefore claim a larger share of payoff. Thus, in multi-issue bargaining the outcome may be less favorable for employers compared to a single-issue agenda. This is in contrast to theoretical models because it is usually assumed that the distribution of bargaining 
power between the two parties is independent of the bargaining agenda. Third, actual bargaining behavior may differ more generally from theoretically assumed bargaining behavior such that the proposed influences of the bargaining agenda on efficiency may not be valid. Fourth, keeping flexibility with respect to employment may be valuable especially when business conditions change during the contract. And, fifth, unions may not fully internalize the disutility of unemployment. If the unions mainly care about the wage of the insiders, this reduces the attractiveness of the multi-issue bargaining relative to the single-issue bargaining.

Our laboratory experiment mainly investigates the first three main hypotheses: whether individuals have a preference for decision authority and whether this preference for decision authority reacts to its cost, whether the distribution of bargaining power depends on the bargaining agenda, and whether efficiency is influenced by the bargaining agenda. All three hypotheses offer a partial explanation of the predominance of the single-issue bargaining agenda model. Our experiment does not directly deal with the hypothesis according to which actual business cycle dynamics favors this model but nevertheless, it allows for consideration of changing business conditions. The last hypothesis - whether unions do not internalize the disutility of employment - is in our view rather difficult to investigate empirically and will not be further addressed here.

Our experiment is based on a non-cooperative game, involving firm-union pairs of players. In the first stage of the game, the firm opts for either a single-issue agenda (SIA) or a multi-issue agenda (MIA) in which the two issues are negotiated simultaneously. In the second stage, the union has to make a bargaining offer conditional on the bargaining model chosen in the first stage. In the third stage of the game, the firm accepts or rejects the offer and chooses the employment level if 
applicable. Lastly, a random draw determines the good or bad state of nature and payoffs are displayed. We implement two experimental treatments of this game, varying the distribution of probabilities of the good and bad states of nature. We use a stranger matching protocol. The game theoretic benchmark solution - which assumes rational and selfish behavior - states that the firm should always choose the multi-issue bargaining model, for both treatments. Our experimental design gives us control with respect to issues that are hardly measurable with field data, e.g., the timing of wage and employment decisions, the structure of the bargaining process, and alternative wage opportunities.

We find that firms choose the single-issue bargaining agenda in most cases. We interpret this as a preference for decision authority. It is in contrast to the theoretical prediction which is based on rationality and selfishness. However, the choice of bargaining agenda does react to the implied cost of decision authority in terms of forgone profits. Unions demand a larger payoff share and disagreement is more frequent in multi-issue bargaining than in single-issue bargaining. Finally, multi-issue bargaining does lead to higher employment, but the efficiency gains are smaller than theoretically predicted. These behavioral regularities indicate why in natural unionized labor markets employers may favor wage-only negotiations as well.

The remaining of this paper is organized as follows. Section 2 presents some related literature. The theoretical model underlying our study is developed in Section 3. Section 4 provides details on the experimental design and procedures. Section 5 reports the data and statistical analyses. Section 6 summarizes the main findings and provides some conclusions. 


\section{Related literature}

Whereas in a laboratory experiment bargaining rules can be controlled and manipulated easily to study their implications, this is far more difficult in natural employer-union conflicts. Thus, most empirical studies using field data test separately either the singleissue or the multi-issue bargaining models through various methods.

The prominent empirical studies on the efficient bargaining model using field data are Brown and Ashenfelter, 1986; Card, 1986; Bean and Turnbull, 1988; Abowd, 1989. The equilibrium condition in the right-to-manage model states that the settled wage is equal to the marginal revenue product of labor, whereas in the efficient bargaining model, this latter corresponds to the negotiated wage diminished by an amount that corresponds to the union's marginal rate of substitution of employment for wage. The alternative wage enters this term whereas it does not influence the right-to-manage equilibrium. Therefore, estimating the influence of the alternative wage in employment equation may offer a test of the efficient bargaining. This test conducted by Brown and Ashenfelter, 1986 rejects the strong efficiency hypothesis required by Pareto optimality (employment should be set such as to equate the marginal revenue product to the alternative wage), but mixed support is found for the weak efficiency hypothesis, according to which employment is determined by both the contract and the alternative wages. Card, 1986 and Abowd and Kramarz, 1993 also conclude that the links between outside wage and employment are not consistent with the efficient bargaining model.

In contrast, MaCurdy and Pencavel, 1986 takes the right-to-manage as the null hypothesis, checking whether the wage is equal to the marginal revenue product of labor, with the same data as Brown and Ashenfelter. Production functions are estimated to determine the marginal productivity of labor. Showing that both alternative wage and 
employment influence productivity, they reject the labor demand equilibrium, as do Bean and Turnbull, 1988. Regarding the public sector, Eberts and Stone, 1986 concludes to efficient bargaining, the estimations in Currie, 1991 accept the strongly efficient bargaining.

A limitation of these results is that they depend largely on the instruments used in the regressions. As regards the estimation procedures, including the alternative wage as a regressor in a reduced-form employment equation and finding it significant is not sufficient to demonstrate the validity of the efficient bargaining model against the rightto-manage model (Pencavel, 1991; Booth, 1995). As a matter of fact, with some specifications of the union's utility function, the contract curve is independent of the alternative wage. Under specific conditions, the alternative wage may also influence the right-to-manage equilibrium. Alternatively, a significant outside option in the regression is compatible with other theories than efficient bargaining, notably the efficiency wage theory or the sequential bargaining model. MaCurdy and Pencavel, 1986 reject the labor demand curve equilibrium model but this is not sufficient to prove that contracts are first-best efficient, and the conclusion depends on the quality of the estimation of the marginal productivity and on the choice of the production function specification. Lastly, if one considers the case in which the labor demand curve and the contract curve coincide (Carruth and Oswald, 1987; Booth, 1995), it becomes impossible to discriminate empirically among these models. In total, the empirical assessment of the effects of the agenda on employment and efficiency remain ambiguous.

In such a context, the opportunity to control the alternative wage, the firm's profit function, the union's utility function and all parameters to isolate the decision process constitutes a serious advantage of laboratory experiments. Early experiments on 
bilateral monopoly have tested alternative models. In Siegel and Fouraker, 1960, a seller and a buyer have to agree on the price and the quantity of a commodity, through a process of offers and counter-offers. In contrast, in Fouraker, Siegel and Harnett, 1962 and Fouraker and Siegel, 1963, the seller is a price leader, while the buyer chooses the quantity. Siegel and Fouraker (1960)'s results show, under condition of equal strength, a tendency toward a contract providing an equal share of maximum joint profits, all the more pronounced as information is complete and as the magnitude of differences in payoffs between contracts at the Pareto optimum and contracts adjacent to this optimum is large. The outcome of the joint negotiation is very close to the Pareto optimal solution and it does not lie on the buyers' marginal revenue curve. In contrast, bargaining under price leadership leads to outcomes which are no longer efficient. However, the pricequantity pairs are located on the demand curve.

While these experiments reveal the importance of the institutional settings on the level of both wages and employment, they do not intend to endogeneize these settings. Yet, examining the origin of the bargaining settings could help in understanding the discrepancy between theoretical models and the reality of bargaining. The main task of this paper is to analyze the relationship between the choice of the agenda and the outcome of the negotiation.

Grounded on the Rubinstein strategic game-theoretic approach, “agenda games” provide a more recent alternative approach of bargaining. Some consider an incomplete information framework using delay as a signaling device (Bac and Raff, 1996), others do not (Weinberger, 2000). In some cases, the agenda is determined exogenously (Fershtman, 1990), whereas in others the agenda is endogenized through a prior bargaining over the agenda (Conlin and Furusawa, 2000). In some games, the 
realization of outcomes is postponed until all issues are negotiated (Ferschman, 1990), whereas others consider a separate implementation (Inderst, 2000). These games with endogenous agendas usually oppose issue-by-issue vs. bundle-bargaining (Lang and Rosenthal, 2001; Younghwan and Serrano, 2004a; Younghwan and Serrano, 2004b). These theoretical analyses have not been empirically tested, as far as we know. Though we analyze the endogeneity of the agenda, our approach differs from these games inasmuch as we do not consider alternating offers and there is no delay in bargaining. In our game, the firm has a full discretion over the agenda but the proposer is the union.

\section{Model and theoretical predictions}

In this section we describe the basic structure of the bargaining game, our experimental design and the behavioral hypotheses.

\subsection{A stochastic model of the firm-union bargaining}

Consider a firm and a union with $N$ members of which $n \leq N$ may be employed. Firm and union care about wage $w$ and employment $n$, which may be determined according to one of two possible agendas to be chosen by the firm: the single-issue bargaining agenda (corresponding to the Right-to-Manage model in the labor economics literature) or the multi-issue bargaining agenda (corresponding to the Efficient Bargaining in the literature). In case of SIA, firm and union bargain about $w$. After a wage settlement, the firm freely chooses $n$. In case of MIA, firm and union bargain about the bundle ( $w$ and $n)$ at the same time. Suppose that the union's utility function $u(w, n)$ and the firm's profit function $\pi(w, n)$ are as follows:

$$
\begin{aligned}
& u(w, n)=n w^{\beta}+(N-n) \bar{u} \\
& \pi(w, n)=p n^{\alpha}-w n
\end{aligned}
$$


with $w>0,0 \leq n \leq N$ as defined above. The term $(N-n)$ represents the number of unemployed members, $\bar{u}$ is the status-quo utility of unemployment, and $p>0$ is the output price received by the firm. The parameters $\alpha$ and $\beta$ (with $0<\alpha, \beta<1$ ) imply decreasing marginal returns of labor for the firm, respectively decreasing marginal utility of money for the union. The union has utilitarian preferences; it cares about the utility of all its members, either employed or unemployed. Output price $p$ is stochastic:

$$
p \in\left\{p_{l}, p_{h}\right\} \text {, with } \operatorname{prob}\left(p_{l}\right)=\theta \text { and } \operatorname{prob}\left(p_{h}\right)=1-\theta
$$

where $p_{l}\left(p_{h}\right)$ represents a low (high) output price. Both parties know the possible realizations of the random price and the probability $\theta$. In MIA the random price is drawn after $w$ and $n$ have been chosen. In SIA $w$ is determined before $p$ is drawn, but $n$ is chosen afterwards with the firm being informed about the realization of $p$. This information structure captures the idea that in SIA employers may react to changes in business conditions via adjusting employment. The parameter $\theta$ influences the profitability of MIA relative to SIA.

To conclude the model we assume that bargaining outcomes are determined via an ultimatum game in which the union states a wage (in SIA and MIA) and an employment level (only in MIA) which may be accepted or rejected by the firm. If the union's offer is accepted by the firm (agreement), payoffs are determined according to (1), (2) and (3). Otherwise (disagreement), the parties earn disagreement payoffs $\pi=\pi^{D}$ and $u=u^{D}$, respectively.

System (1), (2) and (3) is a simple description of a firm-union conflict. Our experimental game, which we introduce below, relies on this structure. The ultimatum 
game gives a strong strategic advantage to the first mover, the union. This can be viewed as a non-cooperative implementation of the so-called "monopoly union case", which is usually modeled as a cooperative Nash Bargaining game where the union has all bargaining power.

\subsection{Experimental game and game theoretic solution}

So far, we described the structural features of our model in general terms for ease of comparison with other models of wage and employment determination. ${ }^{1}$ For the experiment we had to fix numerical values for the parameters and restrict the choice sets. The experimental game is represented by the matrix shown in Appendix A. The choices of wage and employment have been restricted to five different wage levels (rows) and seven different employment levels (columns). Each cell of the matrix displays three payoffs: the firm's payoff if the price is low ( $\pi_{l}=p_{l} n^{\alpha}-w n$, top entry) or high ( $\pi_{h}=p_{h} n^{\alpha}-w n$, middle entry), and the union's payoff (bottom entry). The numbers were computed according to the stochastic model of the employer-union conflict as described in sub-section 3.1 (except for multiplying the payoffs by 100 and rounding off) by relying on the following specifications: $\alpha=0.3, \beta=0.9, p_{h}=2.4, p_{l}=$ 1.4, $N=15, \bar{u}=0.08, w \in\{0.1,0.2, \ldots, 0.5\}$ and $n \in\left\{\frac{3}{2}, \frac{6}{2}, \ldots, \frac{21}{2}\right\}, \pi^{D}=1.25$ and $u^{D}=0.80 .^{2}$ The probability for the low price, $\theta$, was $50 \%$ in some experimental sessions (treatment “50-50”) and 60\% in others (treatment “60-40”). This parameter modification leaves the equilibrium decisions of both players unchanged (as worked out

\footnotetext{
${ }^{1}$ Note that for $p_{l}=p_{h}$ the payoff functions are equivalent to Booth (1995).

${ }^{2}$ A natural alternative specification could have been $u^{D}=N \cdot \bar{u}=1.20$. But we chose to reduce the union's disagreement payoff to make disagreement less attractive. For the theoretical solution this change is irrelevant.
} 
below). However, it influences equilibrium payoffs. We discuss this issue at a later point. The timing of decisions is the following.

Stage 1: the firm chooses the bargaining agenda (MIA or SIA).

Stage 2: the union chooses $w$ (MIA and SIA) and $n$ (only MIA).

Stage 3: the firm accepts or rejects the contract.

Stage 4: the random price is drawn.

Stage 5: the firm chooses $n$ (only SIA).

Applying the notion of subgame perfect equilibrium and assuming that players are riskneutral and rational individuals the game theoretic solution implies that the firm chooses the multi-issue bargaining agenda, that the union demands $w=2$ and $n=7$ and that this contract is accepted. ${ }^{3}$ It can easily be verified that, given the bargaining agenda is MIA, the choice $(w=2, n=7)$ is payoff maximizing for the union subject to the firm's participation constraint (that the firm receives an expected payoff which is at least as large as the disagreement payoff of 125). ${ }^{4}$

If the firm chooses SIA (this choice is off the subgame perfect equilibrium path), the union should demand $w=4$, the firm should accept the contract and subsequently choose $n=1(n=2)$ if the random price turns out low (high). To derive the result for the SIA subgame one has to determine, first, the firm's best reply choices of employment for each possible wage and each realization of the random price. In the payoff matrix in the Appendix the best reply function is indicated by the grey cells. Second, if one considers each possible wage level together with the best reply employment levels, one

\footnotetext{
${ }^{3}$ I.e., row 2 and column 7 . Here and in the following $w$ and $n$ denote rows and columns of the game matrix since experimental choices were labeled this way. This should not be confused with the internal values $w \in\{0.1,0.2, \ldots, 0.5\}$ and $n \in\left\{\frac{3}{2}, \frac{6}{2}, \ldots, \frac{21}{2}\right\}$ that applied in computing the game matrix.

${ }^{4}$ Since entries in the payoff matrix result from multiplying the theoretical values by 100 , the disagreement payoffs were multiplied by 100 as well.
} 
can easily verify that the choice $w=4$ maximizes the union's expected payoff subject to the participation constraint that the firm’s expected payoff is at least 125 .

Table 1 summarizes the rational solution and provides the respective payoffs for each subgame and each treatment. Note that according to the game theoretic solution, the choice of the bargaining rule is not influenced by treatment " $50-50$ ” versus "60-40”. We applied these treatments to vary the profitability of MIA compared to SIA and to check for behavioral stability.

Table 1. Rational choices of wage and employment and according payoffs for each bargaining agenda and treatment

\begin{tabular}{|c|c|c|c|c|}
\hline \multirow{2}{*}{$\begin{array}{l}\text { Treatment } \\
\text { Bargaining agenda }\end{array}$} & \multicolumn{2}{|c|}{$50-50$} & \multicolumn{2}{|c|}{$60-40$} \\
\hline & MIA & SIA & MIA & SIA \\
\hline Wage & 2 & 4 & 2 & 4 \\
\hline Employment & 7 & $p_{l}: 1, p_{h}: 2$ & 7 & $p_{l}: 1, p_{h}: 2$ \\
\hline Union's expected payoff & 283.0 & 201.0 & 283.0 & 195.6 \\
\hline Firm's expected payoff & 174.5 & 156.0 & 154.2 & 144.4 \\
\hline
\end{tabular}

\subsection{Behavioral Hypotheses}

The experiment was designed to test for features of individual behavior that might explain why SIA is predominant in natural firm-union bargaining. A possible reason why the standard bargaining theory cannot provide a satisfactory explanation for this inefficient behavior is that it underestimates or ignores some psychological traits and judgment biases that may explain the departure from the theoretical predictions (for a review on the social psychology of negotiation, see for example Bazerman, Curhan and Moore, 2001; for a recent psychological analysis of what people subjectively value when they negotiate, see Curhan, Elfenbein and $\mathrm{Xu}, 2005)$.

First, firms may choose SIA since they prefer having a choice upon employment rather than accepting or rejecting the offer of unions. We refer to this as "preference for 
decision authority”. It is related to reactance theory and the concept of control in social psychology. Namely, employers may fear of a loss of control when employment would be determined via negotiations. According to reactance theory (Brehm, 1966) individuals attach positive value to the freedom of choice - i.e. having alternative options to choose from - and strive to maintain this freedom. In economics, the intrinsic value of the freedom of choice has been notably explored by Sen, 1988; see also Puppe, 1996 for an axiomatic approach. Maier-Rigaud and Apesteguia, 2003 have conducted an experiment on the influence of the freedom of choice in the Prisoner's Dilemma game and they show that the degree of cooperation is dramatically higher when the subjects have the possibility of choosing the game they play rather than when they are assigned to play the same game.

In real work settings, there could be an interaction of rational and behavioral issues. For example, a rational reason for firms to prefer wage-only bargaining are business cycles (Booth, 1995). Our stochastic game allows firms to consider the consequences of a high versus a low price (good vs. bad business), but nevertheless from a rational perspective they should prefer MIA. Based on these considerations we propose for our experiment:

Hypothesis 1 ("Preference for decision authority"): There will be frequent choices of SIA rather than MIA due to firms’ preference for decision authority.

Note that this hypothesis runs counter to the game theoretic prediction. Our experimental design separates these two alternative explanations of behavior.

Second, we expect that the preference for decision authority - presuming it exists - will be moderated by the implicit cost of choosing SIA rather than MIA. If firms earn less profit in SIA there is a trade-off between a preference for decision authority and a 
preference for money. To study this trade-off our experiment offers two kinds of variations in the cost of SIA: An exogenous variation induced by treatment $50-50$ versus treatment 60-40 and an endogenous variation due to subjects' actual experiences in the course of the experiment. According to the game theoretic solution the cost of SIA (in terms of forgone profit) is larger in treatment 50-50 than in treatment $60-40$. So our data will exhibit variation in the cost of SIA whether or not behavior conforms to the theoretical solution, which allows us to test the following hypothesis:

Hypothesis 2 ("Cost of decision authority"): SIA is chosen less frequent when it is more costly in terms of forgone profit compared to feasible earnings under MIA.

Third, if MIA offers a smaller payoff share to the firm than SIA and if firms care not only for absolute payoffs but also for relative payoffs, firms may find SIA less attractive than MIA. Social justice theory (Homans, 1961) and evidence from bargaining experiments (Roth, 1995) suggest that individuals do care for relative payoffs and reject unfair offers. Using the theoretical solution (table 1) to determine relative payoffs one finds that the firm's payoff share (firm payoff divided by the sum of firm and union payoff) is smaller in MIA. An alternative explanation of a lower firm payoff share in MIA may be that unions feel more powerful when bargaining on two issues rather than one. This issue will be discussed later on. The above arguments lead to the following two predictions:

Hypothesis 3 ("Care for payoff share”): The union offers a smaller payoff share in MIA than in SIA and firms pay attention to their payoff share.

Hypothesis 4 ("Frequency of disagreement"): Given that Hypothesis 3 holds disagreement in bargaining is more frequent in MIA than in SIA. 
Hypothesis 4 is counter to the game theoretic solution which predicts no disagreements for both, MIA and SIA. More generally, rationality predicts not to reject an offer if it grants a payoff that is larger than the disagreement payoff. In the empirical analysis we will therefore control for offers to satisfy the firm’s participation constraint.

Finally, we investigate whether MIA leads to increased employment compared to SIA (given that agreement has been reached). In line with the theoretical solution we predict: Hypothesis 5 ("Employment increase”): Employment is higher under MIA than under SIA.

\section{Experimental procedures}

The experiment was performed at GATE, Groupe d'Analyse et de Theorie Economique, Lyon, using Regate software (Zeiliger, 2000). Five experimental sessions were organized, with each session consisting of 15 periods of playing the above game. Three sessions started with 12 periods of play under the 60-40 treatment followed by 3 periods of play under the 50-50 treatment (within-subject treatment). Two sessions were run in the reverse order: 12 periods of the $50-50$ treatment were followed by 3 periods of the 60-40 treatment. Each session involved 16 volunteer participants. The data from the second part of the experiment were collected for explorative reasons (the impact of a change in the business climate in a within-subject comparison) but the analysis will be based only on between-subject comparisons; i.e., the data of periods 1 to 12 . Thus we analyze a total of 480 observations of union-firm decisions (288 observations in the 6040 treatment and 192 in the 50-50 treatment).

All 80 participants were drawn from the undergraduate population of the Management School of Lyon (40), the Engineering and Textile School of Lyon (20), and the 
Engineer Central School of Lyon (20). No subject was experienced in this sort of experiment and none participated in more than one session. Participants remained anonymous.

At the beginning of a session, the participants were informed about the rules of the game including the probability for a low (high) output price (for periods 1 to 12). At this stage, they were neither informed about the number of periods to be played nor that a second part with a changed probability (periods 13 to 15) would follow. They received instruction sheets for the first part (see Appendix B) and instructions were read aloud by the experimenter to provide common knowledge regarding the game rules, including the payoff matrix and the probability for low (high) output price. Instructions were phrased in neutral terms; the choices of wage and employment were presented as choices of a row and a column of the game matrix. Questions were answered privately by the experimenter. To check for understanding of the decision rules and payoff matrix, the participants had to fill out a questionnaire.

Then, each participant was randomly assigned the role of union (“X-participant”) or firm (“Y-participant”) and kept the same role throughout the session. In each period, subjects were randomly paired and pairs were reconstituted as a new period began. To increase the number of independent observations, we used two terminal servers, with each managing a group of eight subjects (four unions, four firms). Subjects were unaware of this partitioning of the group. At the end of each period, the participants were informed about their respective payoff for the current period and a feedback table displayed their choices and payoffs in all previous periods. After period 12, they received instructions on the second part of the session, but were not informed about the number of periods to come. No questions were allowed. 
On average, a session lasted 45 minutes, excluding the time needed to answer a postexperimental questionnaire and the payment of participants. All transactions were conducted in points and were converted at the end of the session into Euros at 300 points $=€ 1$. At the beginning of the session, each participant received an initial endowment of 1000 points, corresponding to a show-up fee, available for covering possible - though unlikely - losses. Each period the participant's account increased (or decreased in case of a loss) by the payoff obtained in that period. At the end of the session each participant was privately paid in cash in a separate room in order to preserve confidentiality. On average, participants earned $€ 12$.

\section{Experimental results}

\subsection{Summary statistics}

Before testing our behavioral hypotheses we provide some descriptive statistics. Tables 2 and 3 show frequency distributions and mean values of experimental decisions for periods 1 to 12 .

As shown in Table 2, a large majority of firms decide to restrain the bargaining agenda to wage-only negotiations: SIA is chosen in $70 \%$ of the cases in both treatments. Agreement is reached in most but not all games. The acceptance rate ranges between $77 \%$ and $87 \%$ and is lower in MIA than in SIA. Furthermore, in MIA wage is lower and employment is higher than in SIA. Interestingly, in comparison with union demands, agreements lead to decreased wage and increased employment. 
Table 2. Summary statistics (periods 1 to 12 )

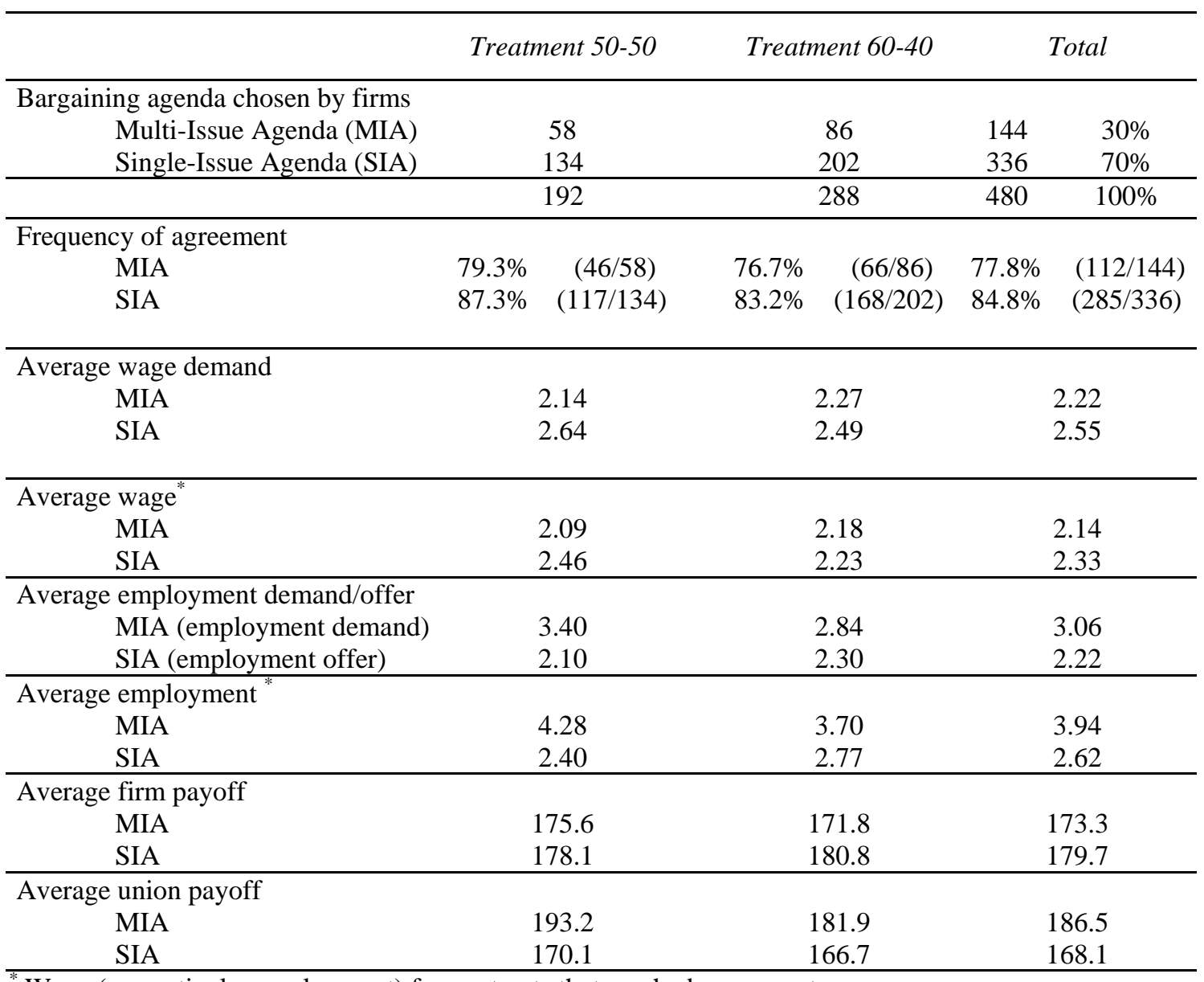

${ }^{*}$ Wage (respectively, employment) for contracts that reached agreement.

A more detailed view upon the unions' demanded wages (MIA and SIA) and demanded employment (only MIA) is provided by Table 3. In SIA only $14 \%$ of the unions claim the theoretically predicted wage $w=4$. Most unions ask for a lower wage. In MIA only 9 out of 144 unions demand a wage-employment pair corresponding to the theoretical solution ( $w=2$ and $n=7)$. While demanded wage equals the predicted level in most cases, employment is usually less than predicted.

In line with the theoretical solution joint payoffs are higher in MIA than in SIA. But, it is only the union's average payoff that increase whereas the firm's average payoff decreases. 
Table 3. Distribution of union demands

\begin{tabular}{|c|r|r|r|r|r|r|r|r|r|r|r|}
\hline \multirow{2}{*}{$\begin{array}{c}\text { Bargaining } \\
\text { agenda }\end{array}$} & \multicolumn{2}{|c|}{ SIA } & \multicolumn{10}{|c|}{ MIA } \\
\cline { 3 - 13 } & \multicolumn{10}{|c|}{} & \multicolumn{10}{|c|}{ Employment Demand } \\
\hline Wage Demand & $\#$ & $\%$ & 1 & 2 & 3 & 4 & 5 & 6 & 7 & Sum & $\%$ \\
\hline 1 & 14 & 4.2 & - & - & - & - & - & - & 1 & 1 & 0.7 \\
2 & 191 & 56.8 & 2 & - & 36 & 32 & 18 & 17 & 9 & 114 & 79.2 \\
3 & 74 & 22.0 & 1 & 9 & 9 & 4 & 3 & - & - & 26 & 18.1 \\
4 & 47 & 14.0 & - & - & - & 2 & 1 & - & - & 3 & 2.1 \\
5 & 10 & 3.0 & - & - & - & - & - & - & - & - & - \\
\hline Sum & 336 & 100.0 & 3 & 9 & 45 & 38 & 22 & 17 & 10 & 144 & 100.0 \\
\hline
\end{tabular}

\subsection{Preference for Decision authority}

Table 4 indicates that firms prefer SIA rather than MIA. The relative frequency of SIA in period 1 is $75 \%$ in both treatments (50-50 and 60-40), while it should be $0 \%$ according to the game theoretical prediction. The frequency changes only slightly in later periods. The data support Hypothesis 1 ("Preference for decision authority").

Table 4. Relative Frequency of SIA in Periods 1 to 12

\begin{tabular}{ccc}
\hline & $\begin{array}{c}50-50 \\
(N=192)\end{array}$ & $\begin{array}{c}60-40 \\
(N=288)\end{array}$ \\
\hline Period & 0.75 & 0.75 \\
1 & 0.63 & 0.54 \\
3 & 0.69 & 0.67 \\
4 & 0.75 & 0.63 \\
5 & 0.69 & 0.54 \\
6 & 0.63 & 0.75 \\
7 & 0.75 & 0.75 \\
8 & 0.81 & 0.79 \\
9 & 0.69 & 0.75 \\
10 & 0.63 & 0.79 \\
11 & 0.69 & 0.75 \\
12 & 0.69 & 0.71 \\
\hline
\end{tabular}

To some degree the frequency of SIA may be due to errors rather than being systematic. Since theory predicts a relative frequency of $0 \%$, any error would imply a deviation from the theoretical solution. Thus, "rationality plus noise" predicts a frequency of SIA equal or below $50 \%$. We test this hypothesis versus the alternative that the frequency of 
SIA is larger than $50 \%$. According to binomial tests based on first period data we can reject the null-hypothesis in favor of the alternative for both treatments $(p=0.039, N=16$ for treatment $50-50$ and $\mathrm{p}=0.012, \mathrm{~N}=24$ for treatment $60-40) .{ }^{5}$ Running the same test on all data (period 1 to 12 ) leads to $\mathrm{p}<0.001$ ( $\mathrm{N}=480$ ). We conclude:

Result 1: The subjects show a preference for decision authority (SIA). This is the case already at the beginning of the experiment. Experience does not drive behavior toward the equilibrium prediction (MIA).

To test Hypothesis 2 ("Cost of decision authority") we consider behavior in period 12, i.e., after the participants have gained experience under both MIA and SIA. Specifically, we run a logit regression analysis (see Table 5) which estimates the probability of choosing SIA in period 12 depending on absolute and relative costs of SIA. Absolute cost of SIA is computed as the difference in expected firm's payoffs between MIA and SIA based on average payoffs earned in periods 1 to 11 under each bargaining agenda. ${ }^{6}$ Similarly, relative cost of SIA is based on the firm's average payoff share (firm payoff divided by the sum of firm and union payoff) under each agenda in periods 1 to 11 . Relative costs in addition to absolute costs were taken into account since subjects might consider relative earnings and/or absolute earnings. Absolute costs and relative costs are only weakly correlated (correlation coefficient: -0.028). The estimated influence of both cost terms is negative; i.e., if decision authority is more costly, it is chosen less likely. We thus state:

\footnotetext{
${ }^{5}$ Statistics for one-tailed, exact tests.

${ }^{6}$ Specifically, we determined the payoff under each agenda for each realization of the random price and then computed expected cost of SIA (payoff MIA minus payoff SIA) accounting for the different probabilities for low (high) price depending on treatment (50-50 versus 60-40).
} 
Result 2: With experience the preference for decision authority is moderated by a concern for the implied cost of the two bargaining agendas.

This result is intuitive but somewhat preliminary. Due to a lack of sufficiently many independent observations we cannot provide a robust statistical analysis. ${ }^{7}$

Table 5. Logit regression analysis of the choice of the bargaining agenda $(1=\mathrm{SIA}, 0=$ MIA)

\begin{tabular}{lcc}
\hline Variable & $\begin{array}{c}\text { Regression } \\
\text { Coefficient }\end{array}$ & Std. Error \\
\hline Constant & 0.237 & 0.474 \\
Absolute Cost of SIA & $-0.015^{*}$ & 0.011 \\
Relative Cost of SIA & $-0.086^{*}$ & 0.054 \\
$\begin{array}{l}\text { Number of observations } \\
\chi^{2}=5.754, \text { Sig.= } 0.056\end{array}$ & 33 & \\
Pseudo $\mathrm{R}^{2}$ & $22.6 \%$ & \\
\hline
\end{tabular}

Note: *: significant at $10 \%$.

\subsection{Offers and Disagreements}

Hypothesis 3 ("Care for payoff share ") predicts that the union offers a smaller payoff share in treatment MIA than in SIA and that firms pay attention to their share. Figure 1 presents the distribution of the firms’ payoff shares (firm payoff divided by sum of firm and union payoffs) as offered by the union for both agendas. ${ }^{8}$

\footnotetext{
${ }^{7}$ The regression is based only on the data of 33 individuals, since not all subjects experienced both bargaining agendas.

${ }^{8}$ In MIA the offered payoff share is solely determined by the union's choice of wage and employment. In SIA the offered payoff share is computed based on the union's choice of wage and assuming a sequentially rational employment decision by the firm. Indeed, employment was chosen sequentially rational in the large majority of cases (240 out of 285 cases [84\%] that had reached agreement under SIA).
} 


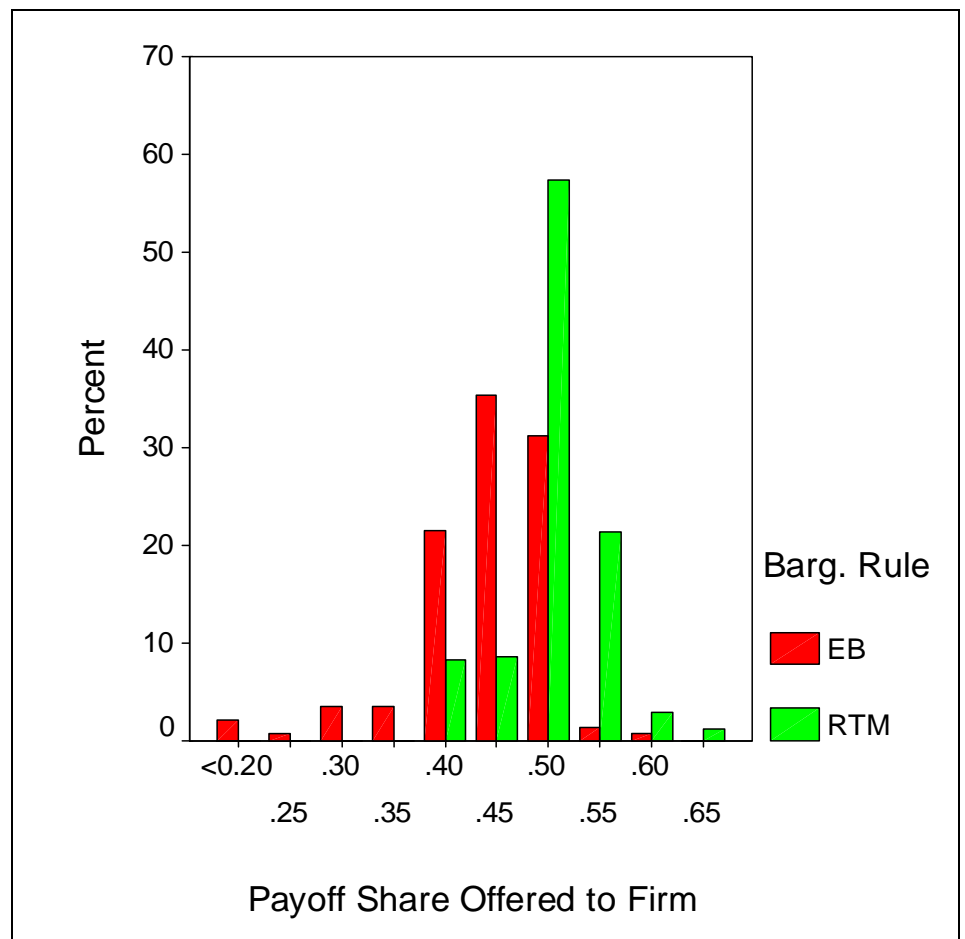

Figure 1. Distribution of payoff shares offered to firm by the union

Indeed, the union offers lower shares in MIA than in SIA. This can be seen also by comparing mean offered shares (see Table 6). The reduction is significant according to a Mann-Whitney U-Test based on first period data $(\mathrm{p}=0.006, \mathrm{~N}=40 \text {, exact, one-tailed })^{9}$ The data are consistent with the comparative statics of the game theoretic solution (see column "Theoretical Values” in Table 6). However, the observed levels of share offers are higher than theoretically predicted; i.e., offers are more generous. The data confirm what has been found in ultimatum game experiments: Offers reflect asymmetries in power (strategic advantage and disadvantage), but are less extreme than rationality theory suggests. Here, the concept of power derives from strategic asymmetries as described by the rational solution of the game. Alternatively, one may argue that the union feels more powerful in MIA than in SIA since in MIA it has more issues to decide

\footnotetext{
${ }^{9}$ There is no significant difference between treatment 50-50 and treatment 60-40 (Mann-Whitney U-Test: $\mathrm{p}=0.16, \mathrm{~N}=40$, exact, one-tailed).
} 
on than in SIA. We refer to this as the "empowerment effect of a broader bargaining agenda”. It is in line with social exchange theory, which proposes that power in negotiation depends on the relative dependence of each party on the other party and that perceptions of power have an influence on negotiations (see Blau, 1964, and Wolfe and McGinn, 2004). Since firms depend more on unions when bargaining is on both, wage and employment, the unions may feel more powerful in MIA than in SIA. Psychologists have also shown that when given a choice, individuals frequently show a misperception of their power to control the situation (“illusion of control”, see Langer, 1975).

Table 6. Average values of payoff shares offered to firms

\begin{tabular}{cccc}
\hline \multicolumn{3}{c}{ Payoff share offered to firms } \\
& & Observed value & Theoretical value \\
\hline MIA & & & \\
& $60-40$ & $43.9 \%$ & $35.3 \%$ \\
& $50-50$ & $45.8 \%$ & $38.1 \%$ \\
SIA & & & \\
& $60-40$ & $50.2 \%$ & $42.5 \%$ \\
& $50-50$ & $50.6 \%$ & $43.7 \%$ \\
\hline
\end{tabular}

We summarize:

Result 3: The payoff share offered by the union to the firm is smaller in treatment MIA than in SIA. This is consistent with the comparative statics of the game theoretical solution. It might also be due to an empowerment effect of a broader bargaining agenda.

Our experiment does not allow to separate the two alternative explanations for result 3.

To test Hypothesis 4 (“Frequency of disagreement”) we run a logit regression analysis (see Table 7) with the acceptance decision (= 1 in case of acceptance, and $=0$ otherwise) as dependent variable and the explanatory variables "offered payoff share", 
“offered absolute payoff”, as well as dummies for treatments (=1 for the $60-40$ Treatment and $=0$ for the 50-50 Treatment) and bargaining agendas (= 1 if SIA and $=0$ if MIA).

Table 7. Logit regression analysis of the acceptance decisions (1=acceptance, $0=$ rejection)

\begin{tabular}{lcc} 
Variable & Coefficient & Std. Dev. \\
\cline { 2 - 2 } & $-13.722^{* * *}$ & 1.655 \\
Offered absolute payoff & $0.045^{* * *}$ & 0.016 \\
Offered relative payoff & $16.104^{* *}$ & 7.615 \\
Bargaining agenda & -0.198 & 0.542 \\
Treatment & 0.122 & 0.343 \\
\hline
\end{tabular}

Note: ${ }^{* * *}$ significant at $1 \%$; ${ }^{* *}$ significant at $5 \%$.

The offered absolute payoff and the offered payoff share exhibit strong positive influences; i.e., more generous offers are accepted more likely. This effect indicates that bargainers care for fairness. It is not consistent with the game theoretical solution. Namely, since the regression uses only those contracts that satisfy the participation constraint (474 out of 480), there should be no correlation between acceptance rate and offered payoff (share) from a rational viewpoint. The regression analysis also shows that after controlling for offered absolute and relative payoffs, neither the bargaining agenda nor the 50-50 versus 60-40 treatment have significant influence on acceptance decisions.

Result 4: Disagreements are more frequent in MIA than in SIA. This effect is not directly caused by the bargaining agenda but indirectly due to more asymmetric (less fair) offers in MIA than in SIA.

\subsection{Employment Level}

Hypothesis 5 ("Employment level”) predicts higher employment in MIA than in SIA. To investigate this we control for differences in the frequency of disagreements by 
considering only those contracts that reached agreement. Figure 2 displays box plots for employment under both treatments and both bargaining agendas. Employment is substantially higher under MIA compared to SIA in both treatments. Since there are no significant differences between treatments (Mann Whitney U-test and T-test), we pool the data of both treatments for further analyses. Table 8 reports that the difference in employment levels between MIA and SIA is statistically significant in the first period as well as overall.

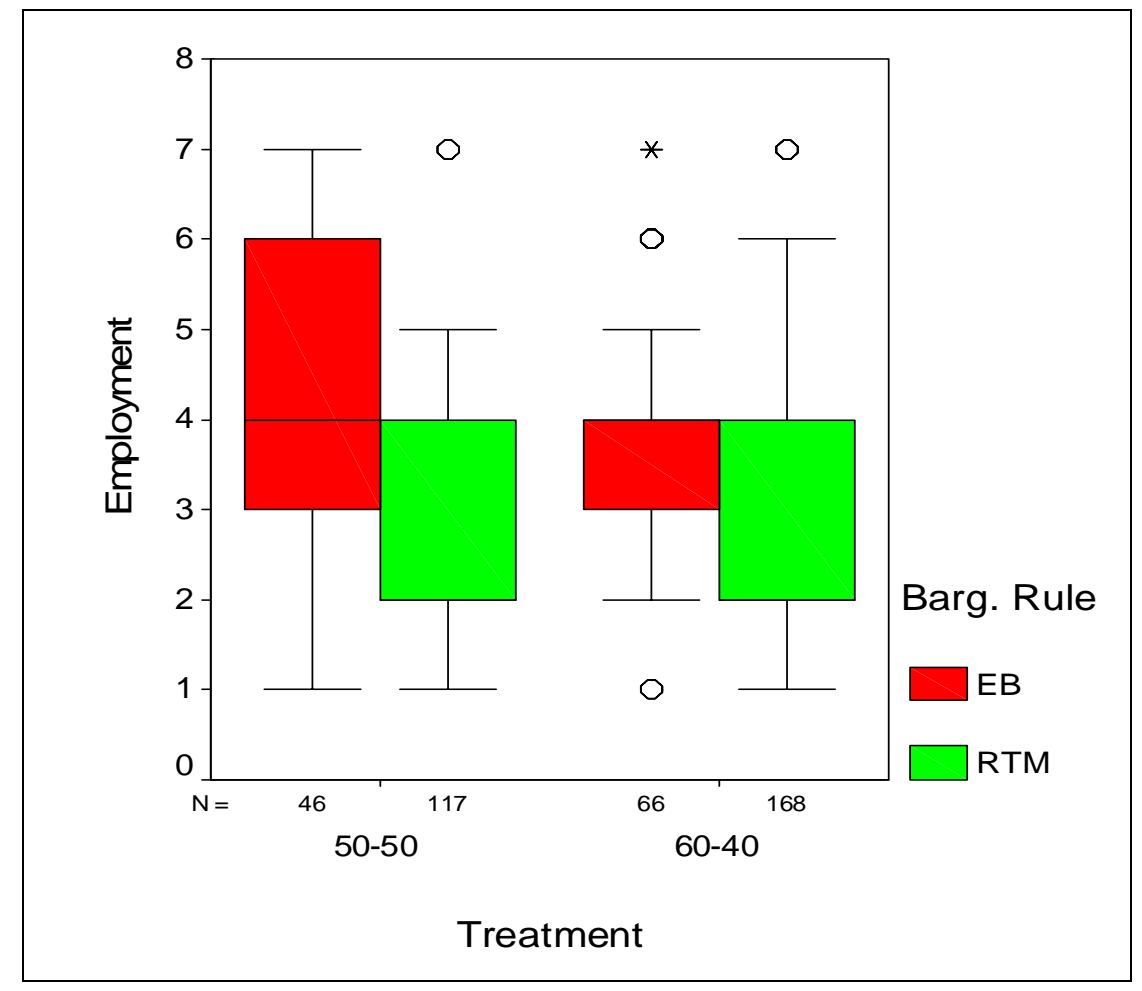

Figure 2. Distribution of employment levels (only accepted contracts) by treatment and bargaining rule

The theoretically predicted employment level in MIA is $n=7$. In SIA it is $n=1(n=2)$ if the realization of the random price is low (high). So, the level of observed employment in MIA is much lower than theoretically predicted, but the difference between agendas (higher employment in MIA) is in line with economic theory. 
However, efficiency gains in MIA are relatively small. This is confirmed by comparing joint payoff of firm and union across treatments (see Table 9). ${ }^{10}$

Table 8. Statistical tests for differences in employment levels

\begin{tabular}{lcl}
\hline \multicolumn{3}{c}{ Average employment levels for accepted contracts } \\
\hline \multicolumn{3}{c}{ Period 1} \\
MIA & 3.13 & $(\mathrm{~N}=8)$ \\
SIA & 2.22 & $(\mathrm{~N}=27)$ \\
Mann-Whitney U-test & $\mathrm{p}=0.037$ & $($ exact, one-tailed) \\
& & \\
& Periods $1-12$ & \\
MIA & 3.94 & $(\mathrm{~N}=112)$ \\
SIA & 1.37 & $(\mathrm{~N}=285)$ \\
Mann-Whitney U-test & $\mathrm{p}<0.001$ & (exact, one-tailed) \\
\hline
\end{tabular}

Table 9. Observed and theoretical joint payoffs for each treatment

\begin{tabular}{ccc}
\hline & $50-50$ & Treatment \\
\hline Average joint payoff (observed) & & $60-40$ \\
MIA & 368.8 & \\
SIA & 348.1 & 353.7 \\
Expected joint payoff (theory) & & 347.5 \\
MIA & 457.5 & 437.2 \\
SIA & 357.0 & 340.0 \\
\hline
\end{tabular}

Theory predicts that joint payoff in MIA is about 100 monetary units higher than in SIA (both treatments), but actually the difference is much smaller (20.7 units in 50-50 and 6.2 units in 60-40). We summarize:

Result 5: Employment is higher in MIA compared to SIA, but efficiency gains of MIA are smaller than theoretically predicted.

\footnotetext{
${ }^{10}$ Joint payoff is a more comprehensive measure of efficiency than employment since it accounts also for differences in agreement rates across treatments and bargaining agendas.
} 


\section{Discussion and Concluding Remarks}

Economic literature contrasts two standard models of employment determination in unionized labor markets. The first model (the Right-to-Manage model) corresponds to a single-issue bargaining agenda (SIA) whereas the second (the Efficient Bargaining model) corresponds to a multi-issue agenda (MIA). The predominance of SIA in real work settings is puzzling given the efficiency gains that should theoretically be achieved in case of MIA. Traditional theoretical models rely on bargaining solutions of cooperative game theory and do not endogenize the choice of the bargaining agenda. A more recent strand of literature relying on Rubinstein-type bargaining models of noncooperative game theory do allow for an endogenous bargaining agenda. In our study we developed a non-cooperative game that allows for choosing the bargaining agenda and reproduces the traditional efficiency gains associated with MIA compared to SIA. The theoretical solution is such that firms should prefer MIA, that MIA should lead to substantially higher employment and that bargaining should lead to agreement.

Contrary we find that SIA is chosen more often than MIA (Result 1), and we interpret this as firm's preference for decision authority. Firms prefer to decide on employment unilaterally rather than via bargaining even though MIA would force the union to tradeoff wage and employment. This behavior can be driven by an intrinsic valuation of the freedom of choice by the individuals, although in our game those who accept to reduce their freedom of choice by enlarging the scope for bargaining keep a veto power on the bargaining partners' offers. The firm's preference for decision authority is, however, moderated by the cost of decision authority (Result 2). Thus, if SIA becomes more expensive in terms of forgone profit, firms will more likely choose MIA. 
Given actual choices in the experiment, MIA is less attractive relative to SIA than theoretically predicted. Namely, the payoff share offered by the union to the firm is smaller in MIA than in SIA and firms do care for relative payoffs (result 3). The latter is documented by a higher frequency of disagreement if the union offers a smaller payoff share (result 4). Both effects work against firms choosing MIA. Whether the smaller offered payoff shares derive from the union's considerations of strategic power (in the sense of the game theoretic solution) or from an "empowerment effect of a broader bargaining agenda” can not be resolved here.

As predicted by our model and more general unionization models, employment (and thus efficiency) is larger under MIA than under SIA. However, the efficiency gains are less pronounced than theory predicts (result 5). So even from a collectively rational perspective the incentive to decide for MIA is flawed relative to the benchmark solution.

The above results are described in terms of the experimental variables and labels. To summarize more generally, we find that participants show a preference for decision authority and choose single-issue bargaining in most cases even though efficiency is lower than in multi-issue bargaining. Furthermore, bargainers care not only for absolute payoffs but also for relative payoffs. The bargaining agenda may influence not only the absolute but also the relative value of offers and consequently the frequency of disagreements.

Our experimental results are to some extent suggestive for real work settings. First, bargaining about both, wage and employment, did induce higher employment levels than wage-only bargaining. It seems that with multi-issue bargaining unions will indeed 
take more into account the tradeoff between several goals. Second, firms may be reluctant to give up the possibility to unilaterally determine employment. They may have a preference for decision authority and they may anticipate an empowerment of the union and more frequent disagreement in case of multi-issue bargaining. Of course, one must be cautious in extrapolating experimental results to real work settings. But they give clear indication that both rational and behavioral considerations drive the choice of the bargaining agenda and the determination of employment levels. 
Appendix A. Payoff matrix according to employment and wage levels

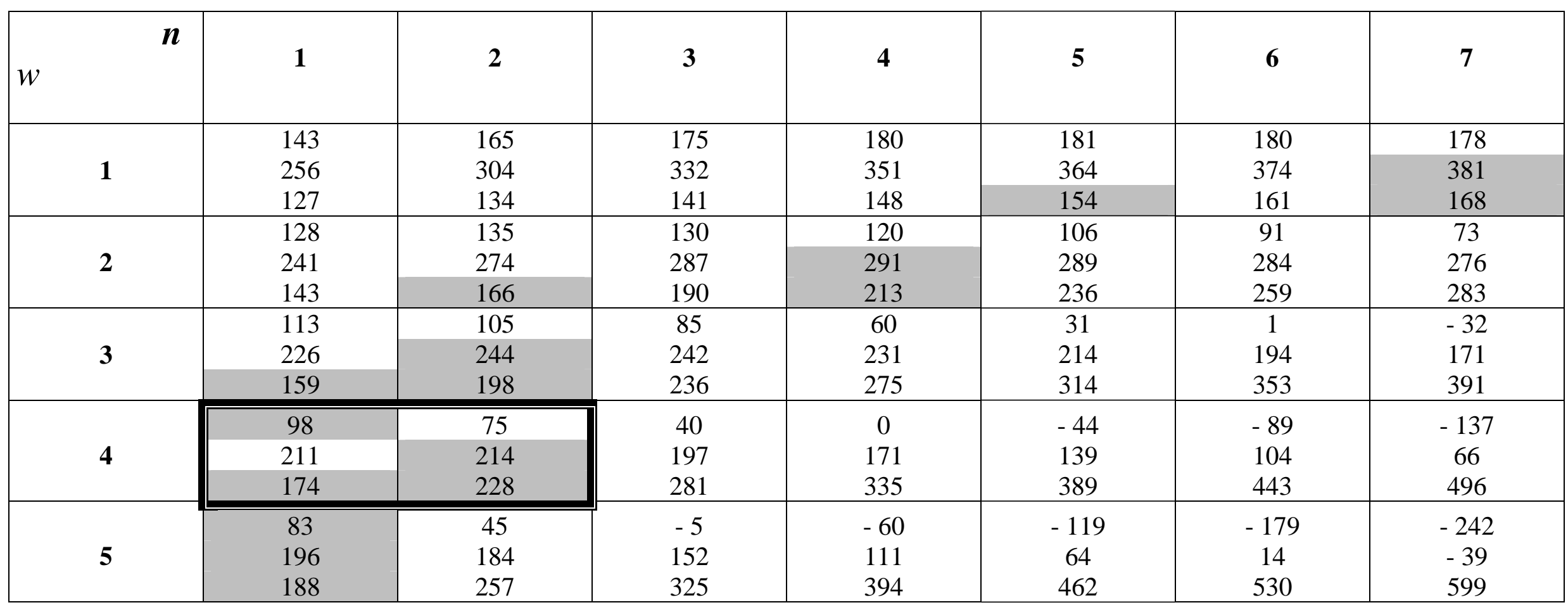

Each cell shows three payoffs: the firm's payoff if the price is low ( $\pi_{l}=p_{l} n^{\alpha}-w n$, top entry) or high $\left(\pi_{h}=p_{h} n^{\alpha}-w n\right.$, middle entry), and the union's payoff (bottom entry).

The dark grey cells represent the maximum employer's payoff given the choice of a wage by the union. The light grey cells represent the maximum union's payoff satisfying the employer's participation constraint. The dark frame indicates the subgame perfect equilibrium given RTM according to the business climate. The light frames indicate the subgame perfect equilibrium given EB according to the business climate.

This table was distributed to the participants during the experiment of course without any indication about the subgame perfect equilibria. No cell had a particular distinctive appearance. 


\section{Appendix B}

\section{Instructions for the 50-50 Treatment}

You are now taking part in an economic experiment. Depending on your decisions during the experiment and the decisions of other participants, you can earn money. During the experiment, your entire earnings will be calculated in points and booked onto an account. At the beginning, your account shows 1000 points, which you receive as initial payment. At the end of the experiment, the total amount of points shown in your account will be converted to Euros at the following rate:

$$
300 \text { points }=€ 1
$$

The experiment is divided into several periods. In each period, you can loose or win points. But note that losses can be avoided surely by your decisions and that possible losses in some periods should be offset by your wins in other periods. If after the final period your account shows a negative amount (this is extremely unlikely), your cash earnings will be zero. At the end of the session, your earnings in points will be converted into Euros and will be paid to you in cash in a separate room, in order to preserve the anonymity of your earnings.

It is prohibited to communicate with the other participants during the experiment. Should you have any questions regarding the instructions, please raise your arm. An experimenter will answer your questions privately. If you violate this rule, we shall have to exclude you immediately from the experiment and from payments.

The group of participants will be subdivided into two categories of roles: $\mathrm{X}$ participants and $\mathrm{Y}$ participants. At the beginning of the experiment, you will discover on your computer screen which role you will play. Each participant keeps his/her role throughout the entire experiment.

In each period, all participants will be randomly matched in pairs (one X participant is matched with one $\mathrm{Y}$ participant) and take decision in their respective role. Interaction is anonymous. No participant will be informed about the name of the participants he/she interacted with.

\section{First period}

In this experiment, decisions are taken in considering the payoff table which has been distributed. This table shows rows 1 to 5 and columns 1 to 7. Each combination of a row and a column determines a cell. In each cell, you see three numbers which are shaded blue, yellow or white corresponding to different payoffs (in points) as explained below. Decisions are made as follows. 
STEP 1

Y participant chooses one of two decision rules: rule A or rule B.

RULE A

STEP 2

- X participant is informed about the chosen rule.

- X chooses one cell, i.e. one of the five rows and one of the seven columns.

\section{STEP 3}

口 Y participant is informed about the chosen row and column.

- Y decides on whether to "accept" or "reject".

\section{- In case of "accept"}

$\checkmark$ A chance move occurs which determines one of two possible outcomes: blue or yellow. The probability for blue is $50 \%$, the probability for yellow is $50 \%$. You may think of these probabilities, for example, as if one takes a single ball out of a basket with 5 blue balls and 5 yellow balls.

$\checkmark \quad$ Payoffs are determined by the chosen cell and the result of the chance move. The blue shaded number in the cell is the payoff of $\mathrm{Y}$ if the chance move turned out blue. The yellow shaded number is the payoff of $Y$ if the chance move turned out yellow. The white shaded number is the payoff of $\mathrm{X}$. $\mathrm{X}$ participant is informed about the decision of $\mathrm{Y}$; $\mathrm{X}$ and $\mathrm{Y}$ participants are informed about the chance move.

\section{- In case of "reject"}

$\mathrm{X}$ participant is informed about Y's rejection. Payoffs are 80 points for $\mathrm{X}$ and 125 points for $\mathrm{Y}$, for this period.

\section{STEP 2}

RULE B

व Participant $X$ is informed about the chosen rule.

X chooses one row among 5 .

\section{STEP 3}

a Y participant is informed about the chosen row.

口 Y decides on whether to "accept" or "reject".

- In case of "accept"

$\checkmark \quad$ A chance move occurs which determines one of two possible outcomes: blue or yellow. The probability for blue is $50 \%$, the probability for yellow is $50 \%$.

$\checkmark \quad$ Y Participant is informed about the chance move.

$\checkmark \quad$ Y chooses one column among 7 . The chosen row (by X) and column (by Y) together determine the chosen cell.

$\checkmark \quad$ Payoffs are determined by the chosen cell and the result of the chance move. The blue shaded number in the cell is the payoff of $\mathrm{Y}$ if the chance move turned out blue. The yellow shaded number is the payoff of $\mathrm{Y}$ if the chance move turned out yellow. The white shaded number is the payoff of $\mathrm{X}$. X participant is informed about the chosen column and the chance move.

- In case of "reject"

$\mathrm{X}$ participant is informed about Y's rejection. Payoffs are 80 points for $X$ and 125 points for $\mathrm{Y}$, for this period.

\section{STEP 4}

End of the period. You are informed on your screen about the earnings of $\mathrm{X}$ and $\mathrm{Y}$ in this period.

\section{Next periods}

It is like the preceding period, except that you are randomly matched with a different participant. 
Payoff table [this is the payoff matrix presented in Appendix A]

The blue shaded numbers are the payoffs of $\mathbf{Y}$ participant if the chance move turned out blue. The yellow shaded numbers are the payoffs of $\mathbf{Y}$ participant if the chance move turned out yellow. The white shaded numbers are the payoffs of $\mathbf{X}$ participant.

New Periods [these instructions, in use for periods 13 to 15 and corresponding to the 60-40 Treatment, were distributed only at the end of the first part of the experiment]

The rules of the experiment are the same as in the previous periods, but the probability for blue is now $60 \%$, the probability for yellow is now $40 \%$. You may think of these probabilities, for example, as if one takes a single ball out of a basket with 6 blue balls and 4 yellow balls. 


\section{References}

Abowd, John M., (1989). "The Effect of Wage Bargaining on the Stock Market Value of the Firm." American Economic Review, 79(4), pp. 774-809.

Abowd, John M. and Kramarz, Francis, (1993). "A Test of Negotiation and Incentive Compensation Models Using Longitudinal French Enterprise Data," J. van Ours, G. Pfann and G. Ridder, Labour Demand and Equilibrium Wage Formation. Amsterdam: Elsevier Science Publishers,

Bac, Mehmet and Raff, H., (1996). "Issue-by-Issue Negotiations: The Role of Information and Time Preferences." Games and Economic Behavior, 13, pp. 125-34.

Bazerman, Max H.; Curhan, Jared R. and Moore, D.A., (2001). "The Death and Rebirth of the Social Psychology of Negotiation," G. J. O. Fletcher and M. S. Clark, Handbook of Social Psychology: Interpersonal Processes. Oxford: Blackwell Publishers, 196-228.

Bean, Charles and Turnbull, P., (1988). "Employment in the British Coal Industry: A Test of the Labour Demand Model." Economic Journal, 98, pp. 1092-104.

Blau, Peter M., (1964). Exchange and Power in Social Life. New-York: Wiley.

Booth, Alison, (1995). The Economics of the Trade Union. Cambridge: Cambridge University Press.

Brehm, J.W., (1966). A Theory of Psychological Reactance. New-York: Academic Press.

Brown, J.N. and Ashenfelter, Orley, (1986). "Testing the Efficiency of Employment Contracts." Journal of Political Economy, 94(3), pp. S40-S87.

Card, David, (1986). "Efficient Contracts with Costly Adjustment: Short-Run Employment Determination for Airline Mechanics." American Economic Review, 76, pp. 1045-71.

Carruth, A. and Oswald, Andrew J., (1987). "On Union Preferences and Labour Market Models: Insiders and Outsiders." Economic Journal, 97, pp. 431-45.

Conlin, M. and Furusawa, T., (2000). "Strategic Delegation and Delay in Negotiations over the Bargaining Agenda." Journal of Labor Economics, 18(1), pp. 55-73.

Curhan, Jared R.; Elfenbein, Hillary Anger and Xu, Heng,2005 "What Do People Value When They Negotiate? Mapping the Domain of Subjective Value in Negotiation," Working Paper, MIT. Boston.

Currie, Janet, (1991). "Employment Determination in a Unionized Public-Sector Labor Market: The Case of Ontario's Teachers." Journal of Labor Economics, pp. 45-65.

Eberts, R.W. and Stone, J.A., (1986). "On the Contract Curve: A Test of Alternative Models of Collective Bargaining." Journal of Labor Economics, 4, pp. 66-81.

Fershtman, C., (1990). "The Importance of the Agenda in Bargaining." Games and Economic Behavior, 2, pp. 224-38.

Fouraker, L.E. and Siegel, S., (1963). Bargaining Behavior. New-York: McGraw Hill.

Fouraker, L.E.; Siegel, S. and Harnett, D.L., (1962). "An Experimental Disposition of Alternative Bilateral Monopoly Models under Conditions of Price Leadership." Operations research, 10, pp. 41-50.

Inderst, R., (2000). "Multi-Issue Bargaining with Endogenous Agenda." Games and Economic Behavior, 30, pp. 64-82.

Lang, K. and Rosenthal, R.W., (2001). "Bargaining Piecemeal or All at Once?" Economic Journal, 111, pp. 526-40. 
Langer, E., (1975). "The Illusion of

Control." Journal of Personality and Social Psychology, 32, pp. 311-28.

MaCurdy, Thomas E. and Pencavel, John, (1986). "Testing between Competing Models of Wage and Employment Determination in Unionized Labor Markets." Journal of Political Economy, 94(3), pp. S3-S39.

Maier-Rigaud, Frank P. and Apesteguia, Jose,2003 "The Role of Choice in Social Dilemma Experiments," Preprints of the Max Planck Institute for Research on Collective Goods. Bonn.

McDonald, Ian M. and Solow, Robert M., (1981). "Wage Bargaining and Employment." American Economic Review, 71(5), pp. 896-908.

Nickell, Stephen J. and Andrews, M., (1983). "Unions, Real Wages and Employment in Britain 1951-79." Oxford Economic Papers, 35(Supplement), pp. 183-93.

Pencavel, John, (1991). Labor Markets under Trade Unionism . Employment, Wages and Hours. Cambridge: Basil Blackwell.

Puppe, Clemens, (1996). "An Axiomatic Approach to "Preference for Freedom of Choice"." Journal of Economic Theory, 68, pp. 174-99.

Sen, Amarthya, (1988). "Freedom of Choice: Concept and Content." European Economic Review, 32, pp. 269-94.

Siegel, S. and Fouraker, L.E., (1960). Bargaining and Group Decision Making. Experiments in Bilateral Monopoly. New-York: McGraw Hill.

Weinberger, C., (2000). "Selective Acceptance and Inefficiency in a Two-Issue Complete Information Bargaining Game." Games and Economic Behavior, 31, pp. 262-93.

Wolfe, Rebecca J. and McGinn, Kathleen L.,2004 "Perceived Relative Power and Its Influence on Negotiations," Harvard NOM Research Papers. Harvard.

Younghwan, In and Serrano, Roberto, (2004a). "Agenda Restrictions in Multi-Issue Bargaining." Journal of Economic Behavior and Organization, 53, pp. 385-99. , (2004b). "Agenda Restrictions in Multi-Issue Bargaining (Ii): Unrestricted Agendas." Economics Letters, 79, pp. 325-31.

Zeiliger, Romain,2000 "A Presentation of Regate, Internet Based Software for Experimental Economics," http://www.gate.cnrs.fr/ zeiliger/regate/RegateIntro.ppt, GATE. GATE. 